\title{
ТОМ \\ Hocus Pocus: using comics to promote skepticism about the paranormal
}

\section{Richard Wiseman, Jordan Collver, Rik Worth and Caroline Watt}

\begin{abstract}
This study investigated the potential for comics to promote skepticism about the paranormal. Participants rated their interest in comics, read a skeptical account of alleged paranormal phenomena in one of three mediums (text, comic, and comic containing an interactive magic trick), and then rated their engagement, skepticism and recall. The text was rated as more interesting and entertaining than the comics, and participants' prior interest in comics positively correlated with engagement and shift in skepticism. This suggests that for certain cohorts, comics may be an effective way to promote engagement and attitude change. The implications for future work are considered.
\end{abstract}

Keywords

DOI

Informal learning; Science and technology, art and literature; Science education

https://doi.org/10.22323/2.20020204

Submitted: 22nd July 2020

Accepted: 1st December 2020

Published: 8th March 2021

Introduction

Educational practitioners have long argued that comics have the potential to promote engagement and learning [e.g., Sones, 1944; Versaci, 2001; Hosler and Boomer, 2011; Muzumdar, 2016]. Work in this area has adopted a variety of approaches, including incorporating commercially available comics into lessons [e.g., Carter, 1988; Kakalios, 2005], and producing bespoke comics that are designed to help provoke debate, enhance literacy skills and convey factual information [e.g., Putnam and Yanagisako, 1982; Barron, 1993; Keogh, Naylor and Wilson, 1998; el-Setouhy and Rio, 2003; Negrete, 2013]. In addition, more theoretically-oriented work research has explored some of the mechanisms that may underpin the educational efficacy of comics, including their frequent use of striking imagery, metaphor, humour and character-driven narratives [e.g., Mayer and Gallini, 1990; Weitkamp and Burnet, 2007; Eilam and Poyas, 2010; Jee and Anggoro, 2012; Cohn, 2020]. One significant strand of this research has examined the role of comics within science education and communication [e.g., Tatalovic, 2009; Hosler and Boomer, 2011; Spiegel et al., 2013; Amaral et al., 2015; Lin et al., 2015]. In a recent review of this work, Farinella [2018] noted that these studies had 
tended to obtain positive outcomes, and that the results suggested that comics enhanced engagement rather than knowledge retention.

Nearly all of the previous research into science communication and comics has involved topics drawn from mainstream disciplines, including evolutionary biology [Hosler and Boomer, 2011], virology [Spiegel et al., 2013], stem cell research [Amaral et al., 2015] and nanotechnology [Lin et al., 2015]. The current study expanded this focus to a novel topic, namely, skepticism about the paranormal. Research suggests that a significant percentage of the public believe in the existence of paranormal phenomena [e.g., Irwin and Marks, 2013; Chapman University, 2018], and that these beliefs are strongly related to positive attitudes towards pseudo-science and conspiracy theories [e.g., Lobato et al., 2014; Clobert and Saroglou, 2015; Irwin, Dagnall and Drinkwater, 2016; Goreis and Voracek, 2019]. In addition, courses that are designed to promote scientific and critical thinking are associated with reduced levels of paranormal beliefs [Morier and Keeports, 1994; Wilson, 2018]. In response, researchers and educational practitioners have created a range of interventions and materials designed to promote skepticism about alleged paranormal phenomena [e.g., Dougherty, 2004; Barberia et al., 2018; Wilson, 2018]. Most of this work has involved conventional approaches, such as lectures, talks, courses, books and magazines. However, a small amount of work has employed comic-based formats, including the 1940s comic 'Ghost Breakers', Hunt Emerson's long-running comic strip 'Phenomenomix' in The Fortean Times, Donald Rooum's 'Sprite' cartoons in The Skeptic, 'What's The Big Idea: The Paranormal' [Wilson and Dewar, 1998], and arguably the many comics based around the 'Scooby-Doo' franchise. To our knowledge, the current study is the first to empirically assess the efficacy of this approach.

The study was also designed to add to existing work examining the educational potential of magic tricks. Educational practitioners have used magic tricks to promote attention, motivation, learning and knowledge retention [e.g., Vidler and Levine, 1981; Frith and Walker, 1983; McCormack, 1985; Broome, 1995]. Wiseman and Watt [2020] recently reviewed the research into this approach and noted that the majority of the studies had yielded positive outcomes. Building on this work, Wiseman, Houstoun and Watt [2020] recently reported how incorporating bespoke magic tricks into an educational video promoted audience engagement and absorption. One strand of this work has examined how magic tricks can help to promote skepticism [e.g., Hansen, 1992; Truzzi, 1997; Benassi, Singer and Reynolds, 1980; Mohr, Koutrakis and Kuhn, 2015]. This work usually involves magicians using tricks to duplicate alleged paranormal phenomena, and has tended to reduce participants' belief in the paranormal [for a review, see Wiseman and Watt, 2020]. Although delivering a similar type of magical experience via the printed page is challenging, magicians have created a genre of 'self-working' tricks in which readers carry out a series of instructions and end up being fooled [e.g., Gardner, 1999; Benkovitz and Setteducati, 1999; Costa, Armstrong and Browne, 2012]. The current study examined the effects of incorporating a well-known self-working 'mind reading' trick into a comic designed to promote skepticism.

Finally, the study also aimed to help resolve two pressing issues surrounding the use of comics within science communication. First, in his review of the area, Farinella [2018] noted that the vast majority of previous studies have been conducted in educational settings, and involved schoolchildren and student 
populations. Only two studies have been carried out in a non-educational context and involved the general public, and both of them suffer from methodological shortcomings. Amaral et al. [2015] asked the public to rate the effectiveness of a variety of visual material (including comics, illustrated newspaper articles and animations) in explaining and promoting stem cell research. Although the ratings tended to be positive, the diverse nature of the material made it problematic to isolate the impact of the comics. Second, Lin et al. [2015] showed that a comic was more effective than a text-based booklet for informing the public about nanotechnology. However, the differing lengths and content of the two sets of stimuli made it problematic to draw firm conclusions from the study. As a result, there is a pressing need for researchers to explore the impact of comics in non-educational settings and among the public. The current study addressed this concern, and involved adult members of the public assessing an online educational comic.

Second, very little work has examined the role that individual differences may play in the impact of educational comics, with Farinella [2018] urging researchers to pay special attention to people's levels of prior interest in comics. In line with this suggestion, the current study explored the effect of participants' prior interest in comics on the various outcome measures.

A variety of approaches have been used to assess the educational impact of comics, including both general quantitative and qualitative methods [Dunst, Laubrock and Wildfeuer, 2018], and those specifically designed to research narrative-based materials [Negrete and Lartigue, 2010]. The current study employed a self-report, quantitative, approach. Prior to the study, the authors created three sets of educational material explaining a psychological principle that can be used to fake a demonstration of alleged mind reading. All three sets had the same narrative and factual details, but one was text-based (Text), one involved a bespoke comic containing an interactive magic trick (Magic Comic) and one contained an identical comic without the trick (Comic). Adult members of the public rated their prior interest in comics and were then randomly allocated to read one set of materials. Participants then rated their engagement with the material, the degree to which it had made them more skeptical about the paranormal, and attempted to recall its factual content. It was predicted that participants' level of engagement, shift towards skepticism and knowledge retention would differ across the three conditions. It was also predicted that in the two comic-based conditions, participant's prior interest in comics would positively correlate with their engagement, shift towards skepticism and recall.

\section{Materials and methods}

\section{Participants}

Participants $(N=534$, mean age $=51.42$ years, $\mathrm{SD}=13.54$; range 18 to 84 years $)$ were recruited via opportunistic sampling, and comprised members of the public responding to calls placed on social media to take part in an online study about the paranormal (see Survey in appendix A). Several studies have validated the use of the web for psychological research [e.g., Crump, McDonnell and Gureckis, 2013; Enochson and Culbertson, 2015]. It was decided in advance to allow data collection for 24 hours and the data was not examined before this endpoint. It wasn't possible to estimate an expected effect size in advance of the study due to the lack of 
previous research in the area. However the resulting sample size had a high chance of detecting a small to medium effect $(d=0.35, p<0.05$, 2-tailed, power $=0.9$ ).

\section{Stimulus material}

Magic Comic. The first author has a background in magic, and the second and third authors have a background in creating science-based comics. They have recently worked together to produce a skeptical comic about the paranormal, and this experiment employed one story from that comic. The narrative was inspired by the true story of a Victorian mind reader named Washington Irving Bishop. Bishop gave public performances in which he appeared to be able to read minds, but was actually using a psychological phenomenon known as muscle reading. The eight-page comic employed striking imagery and humour to describe Bishop's life and abilities. An interactive magic trick was then created to accompany the story. This trick was spread across two pages of the comic. On the first page, the reader was invited to 'test' Bishop's mind reading abilities by selecting one of six locations in which to hide an object. On the following page, Bishop correctly revealed their choice. This trick was accomplished via a mathematical procedure that ensured that readers always chose the same location [see Hoffmann, 1890; Gardner, 1956].

Comic. This comic was identical to the Magic Comic, but the interactive magic trick was replaced with a narrative in which the object was hidden by one of the characters in the story. As a result, readers did not take part in an interactive magic trick or have a magical experience. The images associated with the choice of the locations, and the subsequent reveal of the chosen location, were identical in the Magic Comic and Comic.

Text. The first author produced a text-based version of the comic. This was split into eight sections, and the information in each section duplicated the information presented on each page of the comic. This did not contain any interactive elements.

All materials are available in appendix A.

\section{Questionnaire (see appendix)}

Prior interest in comics. Participants were asked to rate on a 5-point Likert scale how interested they were in comics (1: Not very interested, 5: Very interested).

Shift in skepticism. Participants were asked to rate on a 5-point Likert scale (i) whether the material had made them more skeptical about performers claiming to be able to read minds (1: Definitely no, 5: Definitely yes), and (ii) whether the material had made them more skeptical about the paranormal in general (1: Definitely no, 5: Definitely yes). Participants' scores on each item were treated as separate variables.

Engagement. Participants were asked to rate on a 5-point Likert scale (i) how interesting they found the material (1: Not very interesting, 5: Very interesting), (ii) the degree to which the material had motivated them to find out more about 
science and the paranormal (1: Not very motivated, 5: Very motivated), (iii) how entertaining they found the material (1: Not very entertaining, 5 : Very entertaining), and (iv) how likely they were to share the material with others (1: Very unlikely to share, 5: Very likely to share). Participants' scores on each item were treated as separate variables.

Recall. Participants were presented with four questions about the factual information presented in the material (e.g., According to the material, how did Bishop perform his feats of apparent mind reading?) along with five possible responses for each question (e.g., Genuine psychic powers, Lucky guesswork, Body language, Muscle reading, Cannot remember). The correct answer was assigned 1 point, and participants' scores were averaged across the four items. No other measures were administered or data collected.

\section{Procedure}

The study received ethics approval (number 370-1920/3) from the University of Edinburgh PPLS Research Ethics Committee. Participants were recruited via a call on social media to take part in a study about the paranormal, and the study was carried out on the Qualtrics platform. After giving written informed consent, participants were asked to enter their age and rate their prior interest in comics. They were then randomly assigned to one of three conditions (Text, Magic Comic, Comic). After reading the appropriate material, participants completed the items relating to engagement, shift in skepticism and recall. The time taken for each participant to complete the survey was recorded (in seconds), and participants were not financially rewarded for taking part.

\section{Results}

Data from 17 participants was excluded because they had completed the study in less than 3 minutes, suggesting that they had not spent sufficient time reading and rating the stimulus material (Final cohort: $N=517$, mean age $=51.63$ years, $\mathrm{SD}=13.69$, range 18-84). The three groups did not differ in age (Text: $N=171$, mean age $=52.34$ years, $S D=14.5$; Magic Comic: $N=179$, mean age $=51.27$, $\mathrm{SD}=12.19$; Comic: $N=167$, mean age $=51.26, \mathrm{SD}=14.37 ; F[2,514]=0.40$, $p=0.67$ ), or the time taken to complete the study (Text: mean time $=1020$ seconds, $\mathrm{SD}=4949$; Magic Comic: mean time $=2064, \mathrm{SD}=9310$; Comic: mean time $=1314, \mathrm{SD}=5052 ; F[2,514]=1.10, p=0.33$ : all Scheffe $F$-tests comparing any 2 conditions were non-significant; Comic vs. Magic $=.52$; Comic vs. Text $=.08$; Magic vs. Text $=1.03$ ).

All analyses were pre-planned and were based upon a similar approach employed by Wiseman, Houstoun and Watt [2020]. Between groups ANOVAs were used to examine the three conditions for each of the variables (see Table 1). The findings indicated that the groups significantly differed in terms of how interesting and entertaining the participants found the material. Follow up analyses revealed that the Magic Comic was rated as significantly more interesting than the Comic (Fisher PLSD $=0.22)$, and that the Text was more interesting than the Comic (0.23). In addition, the Text was rated as significantly more entertaining than the Magic Comic (Fisher PLSD $=.22$ ). 
Table 1. Means, SDs (in parentheses), F-values [2,514], $p$-values (significance in bold), and effect sizes (Cohen's $d$; $95 \%$ Confidence Intervals in parentheses) for participants reading the Text $(N=171)$, Magic Comic $(N=179)$ and Comic $(N=167)$.

\begin{tabular}{|c|c|c|c|c|c|c|}
\hline & $\begin{array}{c}\text { Text } \\
\text { Mean } \\
\text { (SD) }\end{array}$ & $\begin{array}{c}\text { Magic } \\
\text { Comic } \\
\text { Mean } \\
\text { (SD) }\end{array}$ & $\begin{array}{l}\text { Comic } \\
\text { Mean } \\
\text { (SD) }\end{array}$ & $F$ & $p$ & $\begin{array}{c}d \\
(95 \% \mathrm{CI})\end{array}$ \\
\hline $\begin{array}{l}\text { Skeptical about } \\
\text { mind reading? }\end{array}$ & $\begin{array}{c}3.17 \\
(1.17)\end{array}$ & $\begin{array}{c}3.12 \\
(1.18)\end{array}$ & $\begin{array}{c}3.15 \\
(1.20)\end{array}$ & 0.07 & 0.93 & $\begin{array}{c}-0.03 \\
(-0.21: 0.15)\end{array}$ \\
\hline $\begin{array}{l}\text { Skeptical about } \\
\text { paranormal? }\end{array}$ & $\begin{array}{c}2.95 \\
(1.08)\end{array}$ & $\begin{array}{c}2.95 \\
(1.13)\end{array}$ & $\begin{array}{c}2.99 \\
(1.12)\end{array}$ & 0.08 & 0.92 & $\begin{array}{c}0.02 \\
(-0.16: 0.20)\end{array}$ \\
\hline How interesting? & $\begin{array}{c}3.90 \\
(0.99)\end{array}$ & $\begin{array}{c}3.83 \\
(1.04)\end{array}$ & $\begin{array}{c}3.53 \\
(1.12)\end{array}$ & 5.83 & .003 & $\begin{array}{c}-0.20 \\
(-0.39:-0.02)\end{array}$ \\
\hline How motivated? & $\begin{array}{c}2.84 \\
(0.91)\end{array}$ & $\begin{array}{c}2.89 \\
(0.99)\end{array}$ & $\begin{array}{c}2.85 \\
(0.99)\end{array}$ & 0.15 & 0.86 & $\begin{array}{c}0.03 \\
(-0.15: 0.22)\end{array}$ \\
\hline How entertaining? & $\begin{array}{c}3.80 \\
(0.94)\end{array}$ & $\begin{array}{c}3.65 \\
(1.02)\end{array}$ & $\begin{array}{c}3.50 \\
(1.10)\end{array}$ & 3.66 & 0.03 & $\begin{array}{c}-0.22 \\
(-0.03:-0.40)\end{array}$ \\
\hline How likely to share? & $\begin{array}{c}2.90 \\
(1.07) \\
\end{array}$ & $\begin{array}{c}2.80 \\
(1.06) \\
\end{array}$ & $\begin{array}{c}2.86 \\
(1.08) \\
\end{array}$ & 0.40 & 0.67 & $\begin{array}{c}-0.07 \\
(-0.25: 0.12) \\
\end{array}$ \\
\hline Recall & $\begin{array}{c}3.71 \\
(0.55)\end{array}$ & $\begin{array}{c}3.57 \\
(0.83)\end{array}$ & $\begin{array}{c}3.56 \\
(0.69)\end{array}$ & 2.43 & 0.09 & $\begin{array}{c}-0.21 \\
(-0.40:-0.02)\end{array}$ \\
\hline
\end{tabular}

Pearson correlations were calculated to assess the relationship between the participants' prior interest in comics and each of these variables in all three conditions (see Table 2). None of the correlations was significant in the Text condition. In contrast, all of the correlations for the Comic were significant, except for recall. For the Magic Comic, all of the items relating to engagement were significant, and those relating to shift in skepticism and recall were non-significant.

A post hoc analysis explored the shift in skepticism further. Participants in the Comic condition were split into two groups on the basis of their prior interest in comics, with those who responded with a ' 1 ' or ' 2 ' being classified as 'Low Interest' $(N=95)$ and those who responded with a ' 3 ', ' 4 ' or ' 5 ' being classified as 'High Interest' $(N=72)$. Unpaired $t$-tests revealed that, compared to those in the 'Low Interest' group, those in the 'High Interest' group obtained significantly higher scores on both measures of shift in skepticism (Skeptical about mind reading: High $M=3.39, \mathrm{SD}=1.20$; Low $M=2.97, \mathrm{SD}=1.17, t$ (unpaired) $=2.27, p(2-t)=0.02$. Skeptical about paranormal: High $M=3.25, \mathrm{SD}=1.72$; Low $M=2.80, \mathrm{SD}=1.04$, $t($ unpaired $)=2.62, p(2-t)=0.009)$. The means of the High Interest group in both analyses were above the mid-point on both scales, indicating that they had become more skeptical. 
Table 2. Pearson correlations between participants' prior interest in comics ( $95 \%$ Confidence Intervals and 2-t $p$-values in parentheses, significance in bold) and each of the variables in the Text $(N=171)$, Magic Comic $(N=179)$ and Comic $(N=167)$.

\begin{tabular}{|l|c|c|c|}
\hline & Text & Magic Comic & Comic \\
\hline Skeptical about & 0.03 & 0.05 & 0.20 \\
mind reading? & $(-0.12: 0.18)$ & $(-0.097: 0.195)$ & $(0.05: 0.341)$ \\
& $(0.72)$ & $(0.50)$ & $(\mathbf{0 . 0 1})$ \\
\hline Skeptical about & 0.004 & 0.04 & 0.22 \\
paranormal? & $(-0.15: 0.15)$ & $(-0.10: 0.185)$ & $0.071: 0.359$ \\
& $(0.96)$ & $(0.58)$ & $(\mathbf{0 . 0 0 5 )}$ \\
\hline How interesting? & 0.015 & 0.24 & 0.31 \\
& $(-0.13: 0.16)$ & $(0.097: 0.373)$ & $(0.166: 0.441)$ \\
& $(0.85)$ & $(\mathbf{0 . 0 0 1})$ & $(\mathbf{0 . 0 0 0 1})$ \\
\hline How motivated? & 0.14 & 0.16 & 0.24 \\
& $(-0.01: 0.28)$ & $(0.014: 0.299)$ & $(0.092: 0.378)$ \\
& $(0.07)$ & $(\mathbf{0 . 0 3})$ & $(\mathbf{0 . 0 0 1})$ \\
\hline How entertaining? & 0.02 & 0.25 & 0.26 \\
& $(-0.13: 0.17)$ & $(0.108: 0.382)$ & $(0.113: 0.396)$ \\
& $(0.79)$ & $(\mathbf{0 . 0 0 0 7}$ & $(\mathbf{0 . 0 0 0 7})$ \\
\hline How likely to share? & 0.12 & 0.25 & 0.23 \\
& $(-0.03: 0.27)$ & $(0.108: 0.382)$ & $(0.081: 0.368)$ \\
& $(0.11)$ & $(\mathbf{0 . 0 0 0 7})$ & $(\mathbf{0 . 0 0 3 )}$ \\
\hline Recall & 0.09 & 0.04 & 0.02 \\
& $(-0.06: 0.24)$ & $(-0.107: 0.185)$ & $(-0.132: 0.171)$ \\
& $(0.25)$ & $(0.58)$ & $(0.81)$ \\
\hline
\end{tabular}

In this study, participants rated their prior interest in comics, read a skeptical account of an alleged paranormal phenomenon in one of three mediums (Text, Magic Comic and Comic), and then rated their shift in skepticism, levels of engagement and recall. Each of the findings will be discussed in turn.

First, there were no significant differences in participants' shift towards skepticism (for either demonstrations of mind reading or the paranormal in general) across the three conditions. However, an examination of the correlational data revealed a more nuanced and interesting pattern. For the Text, the correlations between participants' prior interest in comics and the skepticism-related ratings were not significant. However, for the Comic, both of these correlations were highly significant. This strongly suggests that for individuals with an interest in comics, the medium may present an effective way of fostering skepticism. Future work could further explore this effect, perhaps investigating how comics can be used to engender other forms of attitudinal change associated with equally controversial areas, such as climate change and the need for vaccinations. In addition, participants in this study were responding to postings on social media about a study concerning the paranormal. As such, many of those taking part may have had an interest in, and existing beliefs about, the topic. This cohort is important because people frequently seek out information associated with their existing interests and beliefs, however, future work could examine whether the present findings are replicated among other participant populations. Finally, a qualitative study could be conducted to obtain greater insights into both the nature of any shifts towards greater skepticism and the mechanisms underpinning these changes. 
Second, in terms of engagement, there were no significant differences between the conditions in terms of participants' motivation to discover more about science and the paranormal, or to share the material with others. However, the Magic Comic was rated as significantly more interesting than the Comic. This finding is in line with previous work showing that the inclusion of magic tricks within educational material promotes engagement [Wiseman and Watt, 2020; Wiseman, Houstoun and Watt, 2020]. On a theoretical level, this might be due to magic tricks generating key epistemic emotions that promote engagement [e.g., Vogl, Pekrun, Murayama, Loderer and Schubert, 2019; Vogl, Pekrun, Murayama and Loderer, 2020], such as curiosity and surprise [e.g., Danek et al., 2015; Ozono et al., 2020]. Future work in this area could explore the types of tricks that are especially effective in this regard and how they are best integrated into comics. Contrary to expectations, for the Magic Comic, the correlations between participants' prior interest in comics and the skepticism-related items were not significant. However, the trick was not directly related to the skeptical message presented in the comic (namely that some demonstrations of alleged telepathy are due to muscle reading) and so it may have acted as a 'seductive detail', wherein interesting but irrelevant material actively disrupts learning [for reviews, see Rey, 2012; Sundararajan and Adesope, 2020]. Several researchers have raised this issue in regard to incorporating magic tricks into educational materials [e.g., Moss, Irons and Boland, 2017; Wiseman, Houstoun and Watt, 2020], and future research could explore this notion within the context of comics. This work could, for instance, involve assessing the degree to which participants' skepticism is influenced by interactive magic tricks that either reinforce a comic's key educational message or are superfluous to that messaging. In addition, future work into these issues could employ qualitative methods to gain a deeper insight into how comics and magic tricks impact on these aspects of engagement.

Also, in terms of engagement, the Text was rated as significantly more interesting than the Comic and more entertaining than the Magic Comic. This is not in line with previous studies showing that comics tend to be associated with higher levels of engagement than text-based material. This discrepancy may be due to the different cohort used in this study compared to previous work. Nearly all of the previous work in the area has been conducted within an educational context, and involved schoolchildren and students [Farinella, 2018]. In contrast, the current study involved an adult population drawn from the general public. As such, it seems likely that the past studies obtained higher levels of engagement because the younger cohort found comics more attractive and/or were more familiar with the medium. This interpretation is supported by the correlational data obtained in the current study. For the Text, none of the correlations between participants' prior interest in comics and the engagement-related items were significant. In contrast, for both the Magic Comic and Comic, all of these correlations reached significance. Taken together, these results suggest that comics have the potential to be more engaging than text-based material, but only to those with a prior interest in the medium. In his review of comics and science communication, Farinella [2018] stressed the importance of researchers exploring whether the results obtained in past studies generalize to the general public, and the results from this current study highlight the importance of this approach. Future work could build on this finding by identifying other individual difference measures that correlate with engagement for educational comics, including, for instance, participants' need for cognition [Petty et al., 2008] and imagery skills [Marks, 1973]. 
Finally, there were no significant differences between the groups for subsequent recall of the material, and none of the correlations between participants' prior interest in comics and recall were significant. This finding is in line with the results that have emerged from some previous work examining the role of comics within science communication [Farinella, 2018], along with other studies investigating whether embedding magic tricks within educational materials enhances memory [e.g., Moss, Irons and Boland, 2017; Wiseman, Houstoun and Watt, 2020]. However, the study tested participants' recall for straightforward factual material almost immediately after they had read the text and comics. In addition, the mean recall scores were high, suggesting that this aspect of the study may contain a ceiling effect. As such, future work could examine the impact that comics might have on participants' memory for more subtle information over a larger period of time.

Future work could build on these results in several ways. For instance, in this study, participants' prior interest in comics was measured using a single Likert-scale item. Additional work could examine other dimensions (such as peoples' enjoyment of comics and prior experience with the medium) and possibly involve constructing a questionnaire that reflects these key dimensions. An alternative, and complementary, approach could also involve participants being interviewed about their prior thoughts about comics, and qualitative analyses being used to identify underlying themes. Finally, future work could also explore the cultural dimensions of these findings. In some cultures, comic books are more prevalent, and widely read, than others. For example, in Mexico, comic books are one of the most frequently consumed forms of media, with some research suggesting that they represent around a third of all publications [Negrete, 2013]. The findings from the current study suggest that comic books may present an especially effective vehicle for science communication and skepticism in such settings, and future work could empirically examine this notion.

This study extends previous work into the role of comics within science communication, focusing on their potential to promote a skeptical attitude towards the paranormal. The study revealed that participants' prior interest in comics was positively correlated with the degree to which the Comic promoted skepticism. There was no difference between the three conditions for engagement, but for the Comic and Magic Comic, participants' prior interest in comics was positively correlated with engagement. Previous work suggests that comics are significantly more engaging than text-based material. However, much of this work has involved schoolchildren and students, and the results from the current study raise concerns about the degree to which previous findings generalize to the wider public. Overall, these findings suggest that future work may benefit from utilizing more diverse cohorts, and identifying the types of individuals for whom comics are especially engaging and persuasive. In doing so, it is hoped that this work will help to build a more comprehensive and nuanced understanding of the potential of comics within science communication. 
Appendix A.

Recruitment and survey

\section{Recruitment}

Participants were recruited via two tweets posted by the authors. The first read 'We are running a study about mind reading \& love $\mathrm{u}$ to take part. Takes 9 mins. Just click here', whilst the second read 'Hey, if you have ten minutes to spare would you like to help me out and take part in a parapsychology experiment?'

\section{Survey}

How old are you (years)?

Please rate how interested you are in comics by choosing a number between 1 (Not very interested) and 5 (Very interested).

$\begin{array}{lllll}1 & 2 & 3 & 4 & 5 \\ \begin{array}{l}\text { Not very } \\ \text { interested }\end{array} & & & & \text { Very } \\ \end{array}$

You are about to see some educational material about a Victorian performer called Washington Irving Bishop. Bishop appeared to be able to read people's minds, and in the story you will discover the truth about his abilities.

\section{Material here}

Please rate how interesting you found the material by choosing a number between 1 (Not very interesting) and 5 (Very interesting).

$\begin{array}{lllll}1 & 2 & 3 & 4 & 5 \\ \begin{array}{l}\text { Not very } \\ \text { interesting }\end{array} & & & & \text { Very } \\ & & & & \\ \text { interesting }\end{array}$

Please rate the degree to which the material motivated you to find out more about science and the paranormal by choosing a number between 1 (Not very motivated) and 5 (Very motivated).

$\begin{array}{lllll}1 & 2 & 3 & 4 & 5 \\ \begin{array}{l}\text { Not very } \\ \text { interested }\end{array} & & & & \\ \end{array}$

Please rate how entertaining you found the material by choosing a number between 1 (Not very entertaining) and 5 (Very entertaining).

$\begin{array}{lllll}1 & 2 & 3 & 4 & 5 \\ \begin{array}{l}\text { Not very } \\ \text { entertaining }\end{array} & & & & \text { Very } \\ \text { entertaining }\end{array}$

Did the material make you more skeptical about performers claiming to be able to read minds? Please choose a number between 1 (Definitely no) and 5 (Definitely yes).

$\begin{array}{lllll}1 & 2 & 3 & 4 & \\ \begin{array}{l}\text { Definitely } \\ \text { no }\end{array} & & & & \begin{array}{l}\text { Definitely } \\ \text { yes }\end{array}\end{array}$


Did the material make you more skeptical about the paranormal in general? Please choose a number between 1 (Definitely no) and 5 (Definitely yes).

$\begin{array}{lllll}1 & 2 & 3 & 4 & 5 \\ \begin{array}{l}\text { Definitely } \\ \text { no }\end{array} & & & & \begin{array}{l}\text { Definitely } \\ \text { yes }\end{array}\end{array}$

Please rate how likely you would be to share the material with others by choosing a number between 1 (Very unlikely to share) to 5 (Very likely to share).

$\begin{array}{lllll}1 & 2 & 3 & 4 & 5 \\ \begin{array}{l}\text { Very unlikely } \\ \text { to share }\end{array} & & & & \begin{array}{l}\text { Very likely } \\ \text { to share }\end{array}\end{array}$

The final few questions are about your memory for information presented in the material. Please choose one of the options or indicate that you cannot remember.

According to the material, how did Bishop perform his feats of apparent mind reading?

Genuine psychic powers

Lucky guesswork

Body language

Muscle reading

Cannot remember

According to the material, how big was Bishop's brain?

Smaller than average

Larger than average

The same as average

The doctors couldn't tell

Cannot remember

According to the material, how did Bishop start his performing career?

As a magician

As a manager for a medium

As a juggler

As a singer

Cannot remember

According to the material, what neurological condition did Bishop suffer from?

Epilepsy

Catatonic trance

Migraines

Motor neurone disease

Cannot remember 
Amaral, S. V., Forte, T., Ramalho-Santos, J. and Girão da Cruz, M. T. (2015). 'I want more and better cells! - An outreach project about stem cells and its impact on the general population'. PLOS ONE 10 (7), e0133753.

https://doi.org/10.1371/journal. pone.0133753.

Barberia, I., Tubau, E., Matute, H. and Rodríguez-Ferreiro, J. (2018). 'A short educational intervention diminishes causal illusions and specific paranormal beliefs in undergraduates'. PloS ONE 13 (1), e0191907.

https://doi.org/10.1371/journal.pone.0191907.

Barron, J. (9th November 1993). 'AIDS message in a subway comic strip; New York City Health Agency teaches about the disease in a soap with a sober focus'. New York Times.

URL: https://www .nytimes.com/1993/11/09/nyregion/aids-message-subway -comic-strip-new-york-city-health-agency-teaches-about.html (visited on 2nd July 2020).

Benassi, V. A., Singer, B. and Reynolds, C. B. (1980). 'Occult belief: seeing is believing'. Journal for the Scientific Study of Religion 19 (4), pp. 337-349. https://doi.org/10.2307/1386128.

Benkovitz, A. and Setteducati, M. (1999). The Magic Show. New York, NY, U.S.A.: Workman Publishing Company.

Broome, S. A. (1995). 'Magic in the classroom'. Beyond Behavior: a magazine exploring behavior in our schools 6, pp. 23-26.

Carter, H. A. (1988). 'Chemistry in the comics: Part 1. A survey of the comic book literature'. Journal of Chemical Education 65 (12), pp. 1029-1035. https://doi.org/10.1021/ed065p1029.

Chapman University (2018). Paranormal America 2018. Chapman University Survey of American Fears. URL: https://blogs . chapman. edu/wilkinson/2018/10/16/par anormal-america-2018/ (visited on 2nd July 2020).

Clobert, M. and Saroglou, V. (2015). 'Religion, paranormal beliefs, and distrust in science: comparing East versus West'. Archive for the Psychology of Religion 37 (2), pp. 185-199. https://doi .org/10.1163/15736121-12341302.

Cohn, N. (2020). 'Your brain on comics: a cognitive model of visual narrative comprehension'. Topics in Cognitive Science 12 (1), pp. 352-386. https://doi.org/10.1111/tops.12421.

Costa, M., Armstrong, J. and Browne, R. (2012). Smoke and mirrors. 1st ed. San Diego, CA, U.S.A.: IDW Publishing.

Crump, M. J. C., McDonnell, J. V. and Gureckis, T. M. (2013). ‘Evaluating Amazon's Mechanical Turk as a tool for experimental behavioral research'. PLOS ONE 8 (3), e57410. https://doi.org/10.1371/journal . pone.0057410.

Danek, A. H., Öllinger, M., Fraps, T., Grothe, B. and Flanagin, V. L. (2015). 'An fMRI investigation of expectation violation in magic tricks'. Frontiers in Psychology 6, 84. https://doi.org/10.3389/fpsyg. 2015.00084.

Dougherty, M. J. (2004). 'Educating believers: research demonstrates that courses in skepticism can effectively decrease belief in the paranormal'. Skeptic 10 (4), pp. 31-33.

Dunst, A., Laubrock, J. and Wildfeuer, J., eds. (2018). Empirical comics research. Digital, multimodal, and cognitive methods. New York, NY, U.S.A.: Routledge. https://doi.org/10.4324/9781315185354.

Eilam, B. and Poyas, Y. (2010). 'External visual representations in science learning: the case of relations among system components'. International Journal of Science Education 32 (17), pp. 2335-2366. https://doi.org/10.1080/09500690903503096. 
Enochson, K. and Culbertson, J. (2015). 'Collecting psycholinguistic response time data using Amazon Mechanical Turk'. PLoS ONE 10 (3), e0116946.

https://doi.org/10.1371/journal.pone.0116946.

Farinella, M. (2018). 'The potential of comics in science communication'. JCOM 17 (01), Y01. https://doi .org/10.22323/2.17010401.

Frith, G. H. and Walker, J. C. (1983). 'Magic as motivation for handicapped students'. Teaching Exceptional Children 15 (2), pp. 108-110. https://doi.org/10.1177/004005998301500212.

Gardner, M. (1956). Mathematics, magic and mystery. New York, NY, U.S.A.: Dover Publications, Inc.

- (1999). Mental magic: surefire tricks to amaze your friends. New York, NY, U.S.A.: Sterling Publishing Company.

Goreis, A. and Voracek, M. (2019). 'A systematic review and meta-analysis of psychological research on conspiracy beliefs: field characteristics, measurement instruments, and associations with personality traits'. Frontiers in Psychology 10, 205. https://doi.org/10.3389/fpsyg. 2019.00205.

Hansen, G. P. (1992). 'Magicians on the paranormal: an essay and review of three books'. Journal of the American Society for Psychical Research 86 (2), pp. 151-185.

Hoffmann, P. (1890). More magic. Philadelphia, PA, U.S.A.: David McKay Publisher.

Hosler, J. and Boomer, K. B. (2011). 'Are comic books an effective way to engage nonmajors in learning and appreciating science?' CBE - Life Sciences Education 10 (3), pp. 309-317. https://doi .org/10.1187/cbe.10-07-0090.

Irwin, H. J., Dagnall, N. and Drinkwater, K. (2016). ‘Dispositional scepticism, attitudes to science, and belief in the paranormal'. Australian Journal of Parapsychology 16 (2), pp. 117-131.

Irwin, H. J. and Marks, A. D. G. (2013). 'The survey of scientifically unaccepted beliefs: a new measure of paranormal and related beliefs'. Australian Journal of Parapsychology 13 (2), pp. 133-167.

Jee, B. D. and Anggoro, F. K. (2012). 'Comic cognition: exploring the potential cognitive impacts of science comics'. Journal of Cognitive Education and Psychology 11 (2), pp. 196-208. https://doi.org/10.1891/1945-8959.11.2.196.

Kakalios, J. (2005). The physics of superheroes. New York, NY, U.S.A.: Gotham Books.

Keogh, B., Naylor, S. and Wilson, C. (1998). 'Concept cartoons: a new perspective on physics education'. Physics Education 33 (4), pp. 219-224. https://doi.org/10.1088/0031-9120/33/4/009.

Lin, S.-F., Lin, H.-S., Lee, L. and Yore, L. D. (2015). 'Are science comics a good medium for science communication? The case for public learning of nanotechnology'. International Journal of Science Education, Part B 5 (3), pp. 276-294. https://doi.org/10.1080/21548455.2014.941040.

Lobato, E., Mendoza, J., Sims, V. and Chin, M. (2014). 'Examining the relationship between conspiracy theories, paranormal beliefs, and pseudoscience acceptance among a university population'. Applied Cognitive Psychology 28 (5), pp. 617-625. https://doi.org/10.1002/acp.3042.

Marks, D. F. (1973). 'Visual imagery differences in the recall of pictures'. British Journal of Psychology 64 (1), pp. 17-24. https://doi.org/10.1111/j.2044-8295.1973.tb01322.x. 
Mayer, R. E. and Gallini, J. K. (1990). 'When is an illustration worth ten thousand words?' Journal of Educational Psychology 82 (4), pp. 715-726.

https://doi.org/10.1037/0022-0663.82.4.715.

McCormack, A. J. (1985). 'Teaching with magic: easy ways to hook your class on science'. Learning 14 (1), pp. 62-67.

Mohr, C., Koutrakis, N. and Kuhn, G. (2015). 'Priming psychic and conjuring abilities of a magic demonstration influences event interpretation and random number generation biases'. Frontiers in Psychology 5, 1542. https://doi.org/10.3389/fpsyg. 2014.01542.

Morier, D. and Keeports, D. (1994). 'Normal science and the paranormal: the effect of a scientific method course on students' beliefs'. Research in Higher Education 35 (4), pp. 443-453. URL: https: //www. jstor.org/stable/40196135.

Moss, S. A., Irons, M. and Boland, M. (2017). 'The magic of magic: the effect of magic tricks on subsequent engagement with lecture material'. British Journal of Educational Psychology 87 (1), pp. 32-42. https://doi .org/10.1111/bjep. 12133.

Muzumdar, J. (2016). 'An overview of comic books as an educational tool and implications for pharmacy'. Innovations in Pharmacy 7 (4), 1. https://doi.org/10.24926/iip.v7i4. 463.

Negrete, A. (2013). 'Constructing a comic to communicate scientific information about sustainable development and natural resources in Mexico'. Procedia Social and Behavioral Sciences 103, pp. 200-209. https://doi.org/10.1016/j.sbspro.2013.10.327.

Negrete, A. and Lartigue, C. (2010). 'The science of telling stories: evaluating science communication via narratives (RIRC method)'. Journal of Media and Communication Studies 2 (4), pp. 98-110. URL: http: //www . academic journals . o rg/article/article1380097133_Negrete\%20and\%20Lartigue.pdf.

Ozono, H., Komiya, A., Kuratomi, K., Hatano, A., Fastrich, G., Raw, J., Haffey, A., Meliss, S., Lau, J. K. L. and Murayama, K. (2020). 'Magic Curiosity Arousing Tricks (MagicCATs): a novel stimulus collection to induce epistemic emotions'. PsyArXiv preprint. https://doi.org/10.31234/osf .io/qxdsn.

Petty, R. E., DeMarree, K. G., Briñol, P., Horcajo, J. and Strathman, A. J. (2008). 'Need for cognition can magnify or attenuate priming effects in social judgment'. Personality and Social Psychology Bulletin 34 (7), pp. 900-912. https://doi.org/10.1177/0146167208316692.

Putnam, G. L. and Yanagisako, K. L. (1982). 'Skin cancer comic book: evaluation of a public educational vehicle'. Cancer Detection and Prevention 5 (3), pp. 349-356.

Rey, G. D. (2012). 'A review of research and a meta-analysis of the seductive detail effect'. Educational Research Review 7 (3), pp. 216-237. https://doi.org/10.1016/j. edurev.2012.05.003.

el-Setouhy, M. A. and Rio, F. (2003). 'Stigma reduction and improved knowledge and attitudes towards filariasis using a comic book for children'. Journal of the Egyptian Society of Parasitology 33 (1), pp. 55-65.

Sones, W. W. D. (1944). 'The comics and instructional method'. Journal of Educational Sociology 18 (4), pp. 232-240. https: //doi .org/10.2307/2262696.

Spiegel, A. N., McQuillan, J., Halpin, P., Matuk, C. and Diamond, J. (2013). 'Engaging teenagers with science through comics'. Research in Science Education 43 (6), pp. 2309-2326. https://doi.org/10.1007/s11165-013-9358-x.

Sundararajan, N. and Adesope, O. (2020). 'Keep it coherent: a meta-analysis of the seductive details effect'. Educational Psychology Review 32 (3), pp. 707-734. https://doi.org/10.1007/s10648-020-09522-4. 
Tatalovic, M. (2009). 'Science comics as tools for science education and communication: a brief, exploratory study'. JCOM 08 (04), A02. https://doi.org/10.22323/2.08040202.

Truzzi, M. (1997). 'Reflections on the sociology and social psychology of conjurors and their relations with psychical research'. In: Advances in parapsychological research. 8. Ed. by S. Krippner. Jefferson, NC, U.S.A.: McFarland \& Company, pp. 221-271.

Versaci, R. (2001). 'How comic books can change the way our students see literature: one teacher's perspective'. The English Journal 91 (2), pp. 61-67. https://doi.org/10.2307/822347.

Vidler, D. C. and Levine, J. (1981). 'Curiosity, magic, and the teacher'. Education 101 (3), pp. 273-275.

Vogl, E., Pekrun, R., Murayama, K. and Loderer, K. (2020). 'Surprised-curious-confused: epistemic emotions and knowledge exploration'. Emotion 20 (4), pp. 625-641. https://doi .org/10.1037/emo0000578.

Vogl, E., Pekrun, R., Murayama, K., Loderer, K. and Schubert, S. (2019). 'Surprise, curiosity, and confusion promote knowledge exploration: evidence for robust effects of epistemic emotions'. Frontiers in Psychology 10, 2474. https://doi.org/10.3389/fpsyg.2019.02474.

Weitkamp, E. and Burnet, F. (2007). 'The chemedian brings laughter to the chemistry classroom'. International Journal of Science Education 29 (15), pp. 1911-1929. https://doi.org/10.1080/09500690701222790.

Wilson, A. and Dewar, N. (1998). What's the big idea? The paranormal. London, U.K.: Hodder Children's Books.

Wilson, J. A. (2018). 'Reducing pseudoscientific and paranormal beliefs in university students through a course in science and critical thinking'. Science and Education 27, pp. 183-210. https://doi .org/10.1007/s11191-018-9956-0.

Wiseman, R., Houstoun, W. and Watt, C. (2020). 'Pedagogic prestidigitation: using magic tricks to enhance educational videos'. PeerJ 8, e9610. https://doi.org/10.7717/peerj.9610.

Wiseman, R. and Watt, C. (2020). 'Conjuring cognition: a review of educational magic-based interventions'. PeerJ 8, e8747. https://doi.org/10.7717/peerj.8747.

Professor Richard Wiseman is the Professor of the Public Understanding go Psychology at the University of Hertfordshire, U.K. He has published widely on the psychology of luck, belief in the paranormal, parapsychology and magic. E-mail: r.wiseman@herts.ac.uk.

Jordan Collver is an illustrator and science communicator specialising in using comics to tell engaging and educational stories about science. He studied MSc Science Communication at The University of The West of England and lives in Bristol, U.K. E-mail: jordan.collver@gmail.com.

Rik Worth studied Philosophy and Theology of Religion at The University of Leeds. He now works as a comic book creator and journalist covering a wide range of subjects including science, society, culture, and politics. His work has been featured in The Independent, Prospect Magazine, The Metro, and Fortean Times. His first non-fiction book is scheduled for release in 2021.

E-mail: rik.worth@theovertake.com. 
Professor Caroline Watt holds the Koestler Chair of Parapsychology at the University of Edinburgh's department of Psychology. Her online parapsychology course and book Parapsychology: A Beginner's Guide aim to promote public understanding of parapsychology. E-mail: Caroline.Watt@ed.ac.uk.

How to cite

Wiseman, R., Collver, J., Worth, R. and Watt, C. (2021). 'Hocus Pocus: using comics to promote skepticism about the paranormal'. JCOM 20 (02), A04.

https://doi.org/10.22323/2.20020204. 